\title{
Different Parameters Variation Analysis of a PV Cell
}

\author{
Md Tofael Ahmed $^{* \mathrm{a}}$,Teresa Gonçalves ${ }^{\mathrm{b}}$, Andre Albino $^{\mathrm{b}}$, Masud Rana Rashel ${ }^{\mathrm{b}}$, Angela Veiga ${ }^{\mathrm{b}}$, Mouhaydine Tlemcani $^{\mathrm{b}}$ \\ ${ }^{* a, b}$ Department of Physics, ${ }^{b}$ Department of Informatics \\ School of Sciences and Technology \\ University of Évora \\ Évora, Portugal \\ E-mail: tahmedbu@gmail.com
}

\begin{abstract}
The paper states an introduction, description and implementation of a PV cell under the variation of parameters. Analysis and observation of a different parameters variation of a PV cell are discussed here. To obtain the model for the purpose of analyzing an equivalent circuit with the consisting parameters a photo current source, a series resistor, a shunt resistor and a diode is used. The fundamental equation of PV cell is used to study the model and to analyze and best fit observation data. The model can be used in measuring and understanding the behaviour of photovoltaic cells for certain changes in PV cell parameters. A numerical method is used to analyze the parameters sensitivity of the model to achieve the expected result and to understand the deviation of changes in different parameters situation at various conditions respectively. The ideal parameters are used to study the models behaviour. It is also compared the behaviour of current-voltage and power-voltage by comparing with produced maximum power point though it is a challenge to optimize the output with real time simulation. The whole working process is also discussed and an experimental work is also done to get the closure and insight about the produced model and to decide upon the validity of the discussed model.
\end{abstract}

Keywords-PV cell; model; behaviour; method; variation

\section{INTRODUCTION}

The world is moving towards renewable energy sources like solar energy, wind power, hydro power, bio gas etc due to the environmental pollution and global warming problems. The main reason for global warming is the common processes that are using for producing energy in the energy industries because it has a very huge amount of wastage and thus it creates environmental pollution and global warming. The renewably energy industries are environment friendly as it creates very low wastages which is ignorable. Among renewable energy, use of solar energy is becoming very popular day by day due to the low wastage and the availability of the sunlight in the earth. Photovoltaic cell (PV cell) is the main component for producing solar energy in the solar photovoltaic system. It converts sunlight directly into electricity without making any harm to our environment. Among all the renewable energy solutions solar energy is the fastest growing industry. Still, solar panels are not very efficient and researchers all around the world are trying to improve their efficiency and different types of solar panels are producing in the solar panel industries. The single diode solar cell model is an efficient model to analyse the different parameters variation of a PV cell and its five external and internal parameters are analyzed using the ideal values given by the industry [1]. The considered external parameters are solar irradiance $\left(I_{r}\right)$ and cell temperature $(T)$. The internal parameters are series resistance $\left(R_{s}\right)$, shunt resistance $\left(R_{s h}\right)$ and diode reverse saturation current $\left(I_{s}\right)$.

\section{PV Cell Model}

In a PV cell there is an equivalent circuit what is consists of a diode, a series resistor, a current source and a shunt resistance [2].

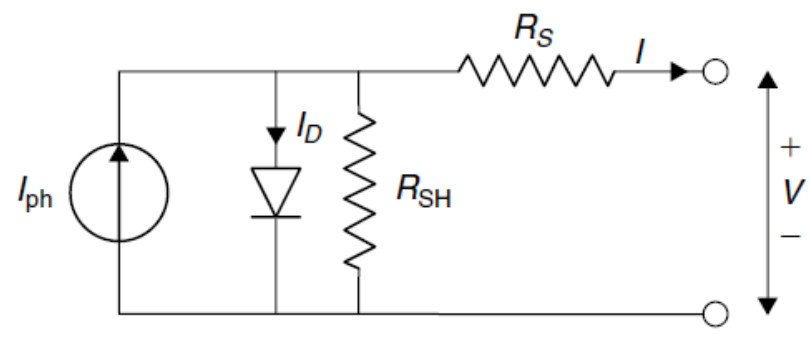

Fig. 1. PV equivalent circuit.

From the above equivalent circuit we can find the load current of the following equation [2][3][4][5][6]:

$$
I=I_{p h}-I_{S}\left(\exp \left(\frac{q V+q R_{S} I}{N K T}\right)-1\right)-\frac{V+R_{S} I}{R_{s h}}
$$

Shockley diode equation is:

$$
I_{d}=I_{S}\left(\exp \left(\frac{q V+q R_{S} I}{N K T}\right)-1\right)
$$

And, the current across the shunt resistor is:

$$
I_{s h}=\left(\frac{V+R_{S} I}{R_{s h}}\right)
$$

Simplifying the equation we have, 


$$
I=I_{p h}-I_{d}-I_{s h}
$$

By putting the values of (2) and (3) at (4) we get,

$$
I=I_{p h}-I_{s}\left(\exp \left(\frac{q V+q R_{s} I}{N K T}\right)-1\right)-\left(\frac{V+R_{s} I}{R_{s h}}\right)
$$

So, it is the equation of load current $(I)$ of a photovoltaic cell. From (1) we have,

$$
I=I_{p h}-I_{S}\left(\exp \left(\frac{q V+q R_{S} I}{N K T}\right)-1\right)-\left(\frac{V}{R_{s h}}\right)-\left(\frac{R_{S} I}{R_{s h}}\right)
$$

By calculating we have,

$$
I=\left(\frac{R_{s h} \times I_{s}}{R_{s h}}\right)\left(1-\left(\frac{V}{R_{s h} \times I_{S}}\right)-\exp \left(\frac{q V}{N K T}\right)\right)+I_{p h}
$$

Here, it is considered as the analytical solution of the fundamental equation for the load current (I) under certain $\left(R_{s}=0\right)$ condition [3].

We cannot find directly analytical solution of the equation (1) so we considered the numerical solution in here [7]. Among all of the numerical methods we worked with 'Bisection Method'.

\section{EFFECT OF PARAMETERS VARIATION}

\section{(a) Solar Irradiance Variation Effects}

TABLE I. DIFFERENT SOLAR IRRADIANCE (Ir)

\begin{tabular}{|c|c|c|}
\hline Name & Value & Unit \\
\hline Solar Irradiance (Ir) & $500,1000,2000$ & $\mathrm{w} / \mathrm{m}^{2}$ \\
\hline
\end{tabular}

With the increase of solar radiation there is increase of current-voltage (I-V) curve and its maximum point also [3],[4]. If we see the variation from $500 \mathrm{Wm}^{-2}$ to $1000 \mathrm{Wm}^{-2}$ then we find $\mathrm{I}_{\mathrm{sc}}$ increases $1.85 \mathrm{~A}$ and $\mathrm{V}_{\mathrm{oc}}$ increases $0.01 \mathrm{~V}$. And, from $1000 \mathrm{Wm}^{-2}$ to $2000 \mathrm{Wm}^{-2}, \mathrm{I}_{\mathrm{sc}}$ increases $4.3 \mathrm{~A}$ and $\mathrm{V}_{\text {oc }}$ increases $0.025 \mathrm{~V}$. The impact on the power-voltage curve is that while there is increase of solar radiations there is increase of $\mathrm{P}-\mathrm{V}$ curve and maximum power output also. Here, with the variation from $500 \mathrm{Wm}^{-2}$ to $1000 \mathrm{Wm}^{-2}, \mathrm{~V}_{\mathrm{oc}}$ increases $0.01 \mathrm{~V}$ and $\mathrm{P}$ increases $1.39 \mathrm{~W}$. And, from 1000 $\mathrm{Wm}^{-2}$ to $2000 \mathrm{Wm}^{-2}, \mathrm{~V}_{\text {oc }}$ increases $0.025 \mathrm{~V}, \mathrm{P}$ increases 3.387
W. Maximum power output goes at the end 1.517 watt to 6.273 watt as the effect of change of radiations.

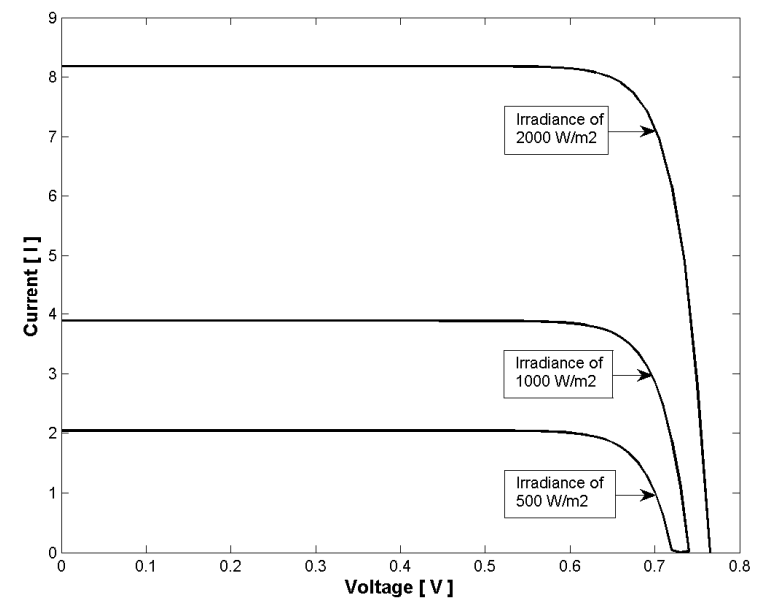

Fig. 2. I-V curve for different solar irradiance.

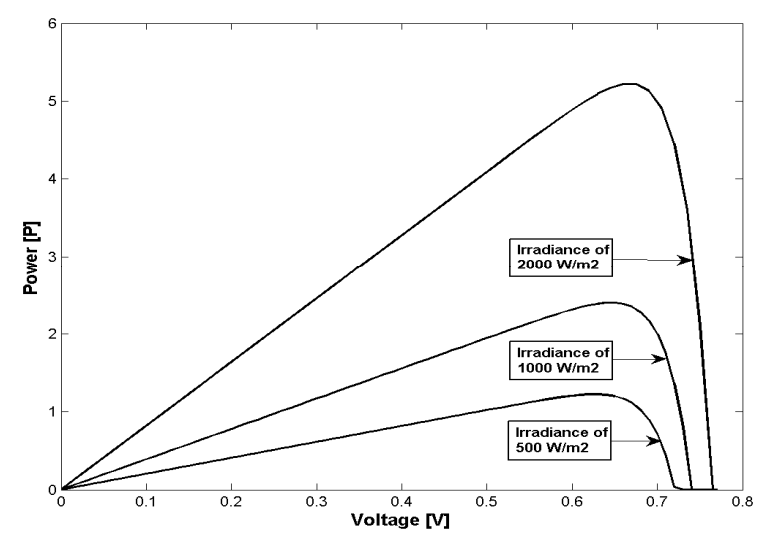

Fig. 3. P-V curve for different solar irradiance.

\section{(b) Effect of varying Cell Temperature}

$$
I_{S}(T)=I_{S}\left(\frac{T}{T_{\text {nom }}}\right)^{3} \exp \left[\left(\frac{T}{T_{\text {nom }}}-1\right) \frac{E_{g}}{N V_{t}}\right]
$$

TABLE II. DIFFERENT CELL TEMPERATURE (T)

\begin{tabular}{|c|c|c|}
\hline Name & Value & Unit \\
\hline Temperature (T) & $20,40,60$ & ${ }^{\circ} \mathrm{C}$ \\
\hline
\end{tabular}

If we increase the cell temperature then there is increase of short circuit current (Isc) and decrease in open circuit voltage (Voc)[5]. 


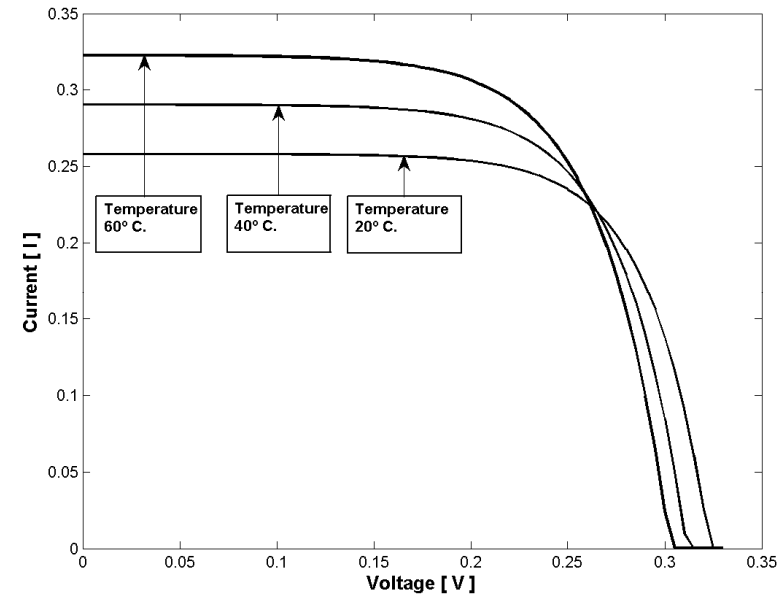

Fig. 4. I-V curve for different temperature.

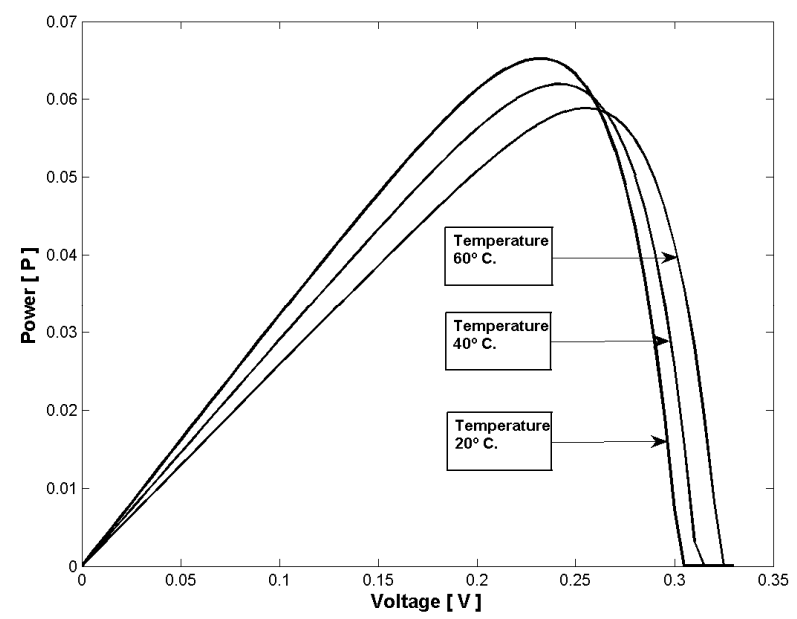

Fig. 5. P-V curve for different temperature.

From $293.15 \mathrm{~K}$ to $313.15 \mathrm{~K}, \mathrm{I}_{\mathrm{sc}}$ increases $0.01 \mathrm{~A}$ and $\mathrm{V}_{\mathrm{oc}}$ decreases $0.035 \mathrm{~V}$. From $313.15 \mathrm{~K}$ to $333.15 \mathrm{~K}, \mathrm{I}_{\mathrm{sc}}$ increases $0.01 \mathrm{~A}$ and $\mathrm{V}_{\mathrm{oc}}$ decreases $0.03 \mathrm{~V}$. There is decrease in open circuit voltage $\left(\mathrm{V}_{\mathrm{oc}}\right)$ if we increase cell temperatures and there is increase in open circuit voltage if we decrease cell temperatures. From $293.15 \mathrm{~K}$ to $313.15 \mathrm{~K}$, Voc decreases $0.035 \mathrm{~V}$ and $\mathrm{P}$ decreases $0.0078 \mathrm{~W}$. From $313.15 \mathrm{~K}$ to 333.15 $\mathrm{K}$, Voc decreases $0.03 \mathrm{~V}$ and $\mathrm{P}$ decreases $0.0685 \mathrm{~W}$. Increase in temperatures cell efficiency drops also.

\section{(c) Effect of varying Series Resistance (Rs)}

TABLE III. DIFFERENT SERIES RESISTANCE (Rs)

\begin{tabular}{|c|c|c|}
\hline Name & Value & Unit \\
\hline Series Resistor (Rs) & $1,4,6$ & Milliohm \\
\hline
\end{tabular}

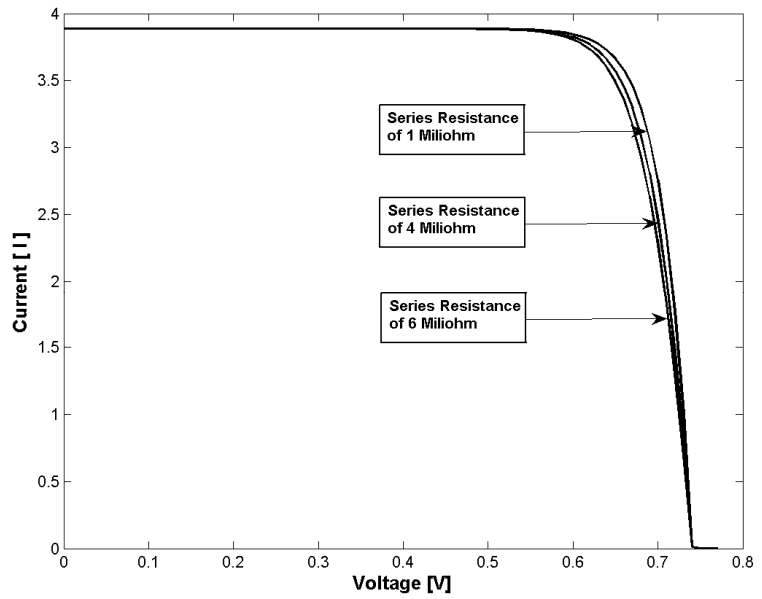

Fig. 6. I-V curve for different Series Resistance[4].

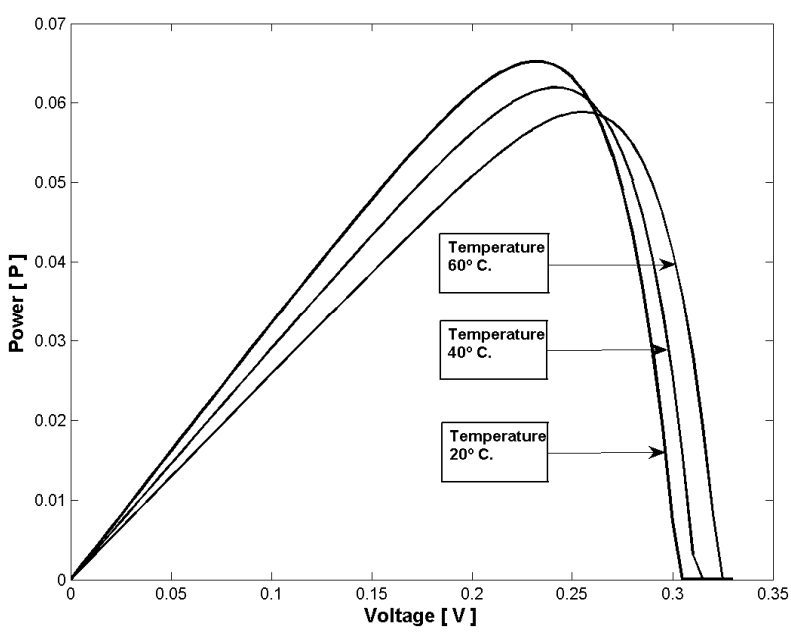

Fig. 7. P-V curve for different Series Resistance.

Though series resistance in a PV circuit is very low but there is less effects of its variation. After observing with the changes from 1 Milliohm, 4 Milliohm to 6 Milliohm it is found that the short circuit current changes slightly and open current voltage remains same. There is decrease in current-voltage curve with the increase of series resistances. With the increase of series resistances there is decrease in power-voltage $(\mathrm{P}-\mathrm{V})$ curve resulting the change in maximum power point. With the decrease of series resistances there is increase in $\mathrm{I}-\mathrm{V}$ and $\mathrm{P}-\mathrm{V}$ curves with increase in maximum power point. MPPT (Maximum Power Point) strongly depends on series resistances.

\section{(d) Effect of varying Shunt Resistance (Rsh)}

The equation for a solar cell in presence of the shunt resistor (Rsh) is: 


$$
\mathrm{R}_{\mathrm{Sh}}=\frac{\left(V+R_{S} I\right)}{\left[I p h-I_{S}\left(\exp \left(\frac{q V+q R_{S} I}{N K T}\right)-1\right) I\right]}
$$

Shunt resistance has great impact on current-voltage curve. With the increase of shunt resistance, current-voltage (I-V) increases because while shunt resistance increases short circuit current remains almost same but open circuit voltage increases. It increases fill factor also. But the infinity value for shunt gives the best output[4].

TABLE IV. DIFFERENT SHUNT RESISTANCE (Rsh)

\begin{tabular}{|c|c|c|}
\hline Name & Value & Unit \\
\hline Shunt Resistor (Rsh) & $10,50,1000$ & Ohm \\
\hline
\end{tabular}

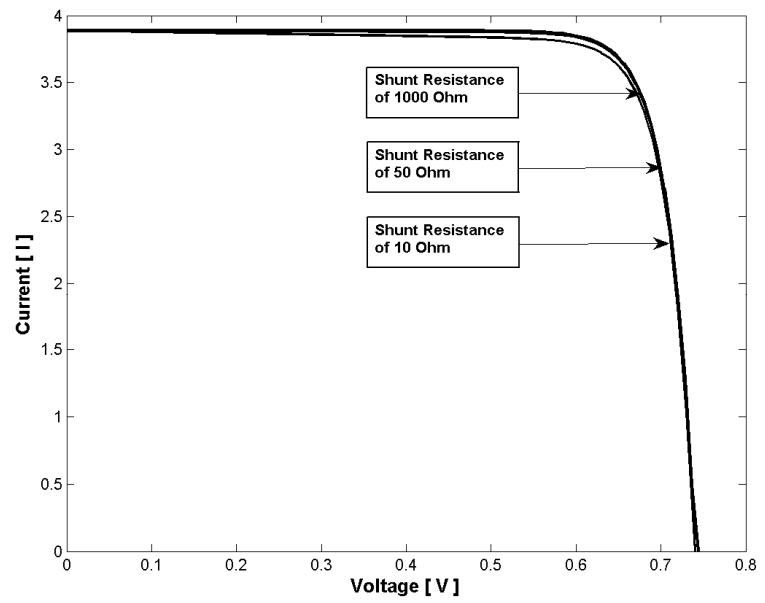

Fig. 8. I-V curve for different Shunt Resistance.

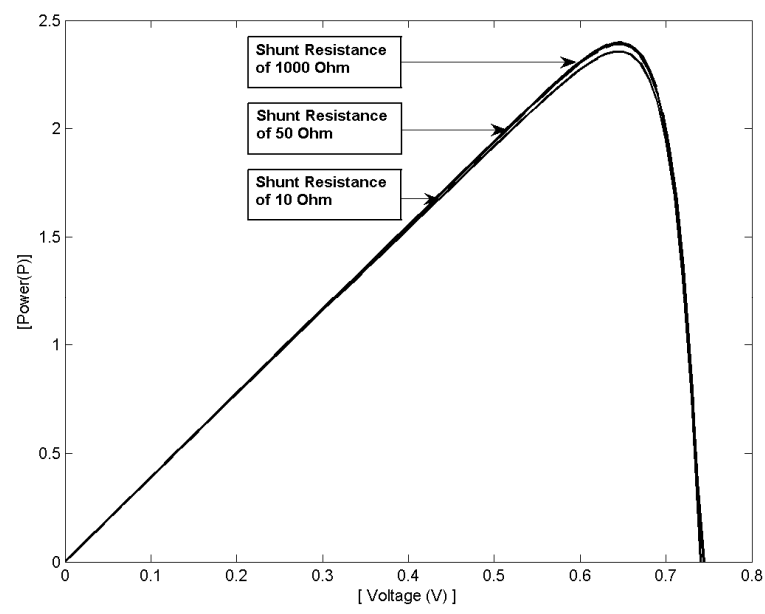

Fig. 9. P-V curve for different Shunt Resistance.

Shunt resistance must be good enough to obtain the maximum power output of a PV cell. Shunt resistance is used to measure high currents and it is connected in parallelly. With the increase of shunt resistance power-voltage $(\mathrm{P}-\mathrm{V})$ increases and it increases maximum power output also. But the infinity value for shunt gives the best output. With the decrease of shunt resistances power output also decreases [8].

\section{(e) Effect of varying Diode Reverse Saturation Current (Is):}

TABLE IV. DIFFERENT REVERSE SATURATION CURRENT (Is).

\begin{tabular}{|c|c|c|}
\hline Name & Value & Unit \\
\hline Saturation Current (Is) & $1,20,100$ & $\mathrm{nA}$ \\
\hline
\end{tabular}

In a current-voltage curve (I-V) with the increase of diode reverse saturation current (Is) open circuit voltage (Voc) decreases and short circuit current (Isc) remains same. From 1 $\mathrm{nA}$ to $20 \mathrm{nA}$, open circuit voltage increases (Voc) $0.53 \mathrm{~V}$ to $0.58 \mathrm{~V}$. From $20 \mathrm{nA}$ to $100 \mathrm{nA}$, open circuit voltage increases (Voc) $0.58 \mathrm{~V}$ to $0.67 \mathrm{~V}$ [9].

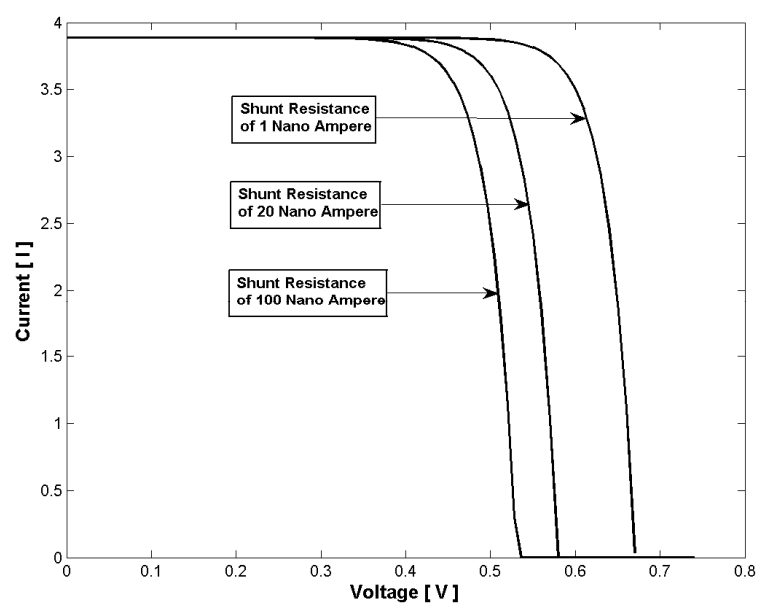

Fig. 10. I-V curve for different Reverse Saturation Current.

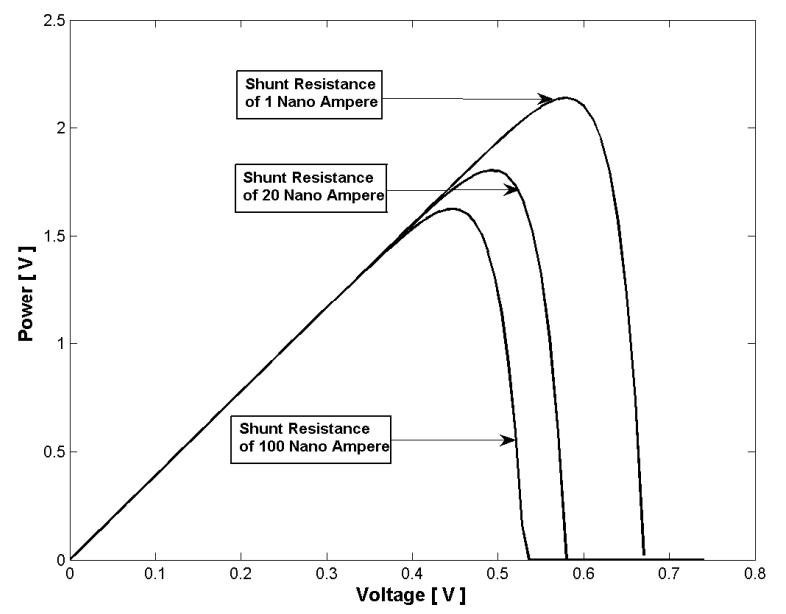

Fig. 11. P-V curve for different Reverse Saturation Current. 


\section{CONCLUSION}

This paper is based on a MATLAB/SIMULINK simulation by using the fundamental circuit equations of a solar photovoltaic cell. We have seen that the simulation enabled the characterization of the solar photovoltaic cell by using different parameters and it shows the great effects of the parameters variation [4]. The changes for current, voltage and power with the maximum power point (MPPT) output are represented in the figures. From the developed work and as expected it is possible to conclude that the PV cell presents different behaviours depending on the internal and external parameters. It is very unpredictable and unimaginable about what may happen for a slight change of a parameter and it is not possible to know without observing the current-voltage and power-voltage curve of a PV cell though all the results are discussed in details at the last section of all the parts of parameters.

\section{ACKNOWLEDGMENTS}

This work is supported by the Erasmus Mundus projects FUSION and LEADER.

\section{REFERRENCES}

[1] Tarak Salmi, Mounir Bouzguenda, Adel Gastli and Ahmed Masmoudi, "MATLAB/Simulink Modelling of Solar Photovoltaic Cell", Int. J. of Ren. En. R. , vol.2, No.2, 2012.

[2] R. Chenni, M. Makhlouf, T. Kerbache, A. Bouzid, "A detailed method for photovoltaic cells", Elsevier, Energy 32 (2007) 1724-1730, 10 December 2005.

[3] Dezso Sera. "Real-time Modelling, Diagnostics and Optimised MPPT for Residential PV systems", CA: Aalborg University, January 2009.

[4] Ahmad A. EL TAYYAN, "A simple method to extract the parameters of the single-diode model of a PV system", Turk J. of Phys (2013) 37: 121-131, 20 March 2013.

[5] G. Farivar, Behzad Asaei, "Photovoltaic Module Single Diode Model Parameters Extraction Based on Manufacturer Datasheet Parameters", IEEE, Int. Con. On

P. and En. (PECon2010), Nov 29- Dec 1, 2010, Kulala Lumpur, Malaysia.

[6] Adel A. Elbaset, H. Ali, M. Abd-El Sattar, "Novel sevelparameter model for photovoltaic modules", Elsevier, Solar Energy Materials \& Solar Cells 130 (2014) 442-455, 10 July 2014.
[7] M.U. Siddiqui, M. Abido, "Parameter estimation for fiveand seven parameter photovoltaic electrical models using evolutionary algorithms", Elsevier, 7 July 2013.

[8] Md Tofael Ahmed, Mouhaydine Tlemcani. "Analysis of Five Parameters model of Photovoltaic cells", INCORE 2016.

[9] T. Gonçalves, Md T. Ahmed, M. R. Rashel, M. Tlemcani, "Conception and Characterization of Photovoltaic Cells", G-LINK 2016. 